\title{
KEPERCAYAAN ANIMISME-DINAMISME SERTA ADAPTASI KEBUDAYAAN HINDU-BUDHA DENGAN KEBUDAYAAN ASLI DI PULAU LOMBOK-NTB
}

\author{
Ahmad Afandi \\ Pendidikan Sejarah, Universitas Muhammadiyah Mataram, afandi190384@gmail.com
}

\begin{abstract}
INFO ARTIKEL
RiwayatArtikel:

Diterima: 03-11-2016

Disetujui: 05-12-2016

\begin{tabular}{ll}
\hline Kata Kunci: \\
1. & Kepercayaan \\
animisme-dinamisme, \\
2. \\
3. & Kebudayayaan Hindu- \\
& Budha, \\
4. & Suku Sasak
\end{tabular}

ABSTRAK

Abstrak: Tulisan ini bertujuan untuk menjawab permasalah (1) bagaimana kepercayaan primitif masyarakat (kepercayaan asli), dan (2) akulturasi kebudayaan Hindu-Budha dengan kebudayaan asli di Pulau Lombok-NTB. Penelitian ini menggunakan metode historis dengan tujuan untuk mendeskripsikan dan mnganalisis peristiwa-peristiwa dimasa lampau. Teknik pengumpulan data menggunakan teknik heuristik dan analisis data bersifat analisis data kualitatif. Hasil kajian ini dapat disimpulkan bahwa kepercayaan awal masyarakat Sasak di Pulau Lombok dipengaruhi oleh kepercayaan religius magis. Pada masyarakat Sasak dikenal juga kepercayaan animism, dinamisme dan totemisme. Kebudayaan masyarakat sebelumnya, setelah kedatangan pengaruh Hindu-Budha terutama setelah pengaruh kerajaan Hindu Bali menganeksasi secara defakto kerajaan Lombok di Mataram Cakra Negara, beberapa kebudayaan yang di bawa oleh orang-orang Bali mampu beradaptasi dengan budaya local, bahkan sampai saat ini budaya yang dikembangkannya tersebut menjadi salah satu budaya dari masyarakat Sasak, seperti dalam hal kesenian, bangunan, aksara dan lain sebagainya.

This paper aims to answer the problems (1) how the primitive belief of the community (original belief), and (2) acculturation of Hindu-Buddhist culture with indigenous culture in Lombok Island-NTB. This study uses historical method with the aim to describe and analyze the events of the past. Data collection techniques using heuristic techniques and data analysis are qualitative data analysis. The results of this study can be concluded that the initial belief of the Sasak community on Lombok Island is influenced by magical religious beliefs. In Sasak society also known animist beliefs, dynamism and totemism. Previously, after the arrival of Hindu-Buddhist influences, especially after the influence of the Hindu Balinese empire defacto the Lombok kingdom in Mataram Cakra Negara, several cultures brought by the Balinese are able to adapt to the local culture, even today the culture it develops become one of the cultures of the Sasak community, as in terms of art, buildings, script and so forth.
\end{abstract}

\section{A. LATAR BELAKANG}

Dalam memahami pengalaman masa lalu manusia, dimana suatu kelompok masyarakat belum mengenal tulisan, selalu melihat alam sebagai bagian yang terpenting dalam menentukan perubahan diri dalam lingkungannya. Alam merupakan realitas kehidupan dan dirinya merupakan bagian dari alam. Manusia pada masa lalu masih memiliki sikap yang sangat menghormati bahkan mengultuskan alam. Alam memiliki kekuatan yang sangat menentukan kehidupan manusia. Perubahan yang terjadi pada diri manusia tidak lepas dari kekuatan-kekuatan yang terjadi pada hukum alam. Asal-usul kejadian yang terjadi pada lingkungan alam atau pada diri manusia, sangat ditentukan oleh kekuatan-kekuatan yang berada di luar diri manusia. Kekuatan-kekuatan itu dapat berupa hukum alam itu sendiri atau tokoh-tokoh dewa atau figure-figur tertentu yang dianggap memiliki kesaktian.
Dengan demikian pada masyarakat masa lalu, khususnya masyarakat yang belum mengenal tulisan, melihat asal usul dan kejadian itu bersifat religio-magis.

Pemikiran yang bersifat religius-magis ini secara umum dapat berupa kepercayaan yang disebut animismdinamisme dan bisa berupa totemisme. Namun seiring waktu ketika kebudayaan Hindu-Budha dari India sekitar abad k2-5 memberi corak lain dalam budaya Indonesia yang secara langsung dapat di katakana terjadi akulturasi budaya. Dilihat secara lebih luas bukan hanya kebudayaan spiritual seperti keagamaan yang di pengaruhi oleh HinduBudha ini melainkan kebudayaan yang sifatnya materil lainnya. Persebarannya di Sumatra dan di Jawa pada masa awal telah memungkinkannya untuk menyebar ke seluruh nusantara, semisal Bali dan Lombok.

Menurut Takdir Alisyahbana, 1988) bahwa kbudayaan Indonesia asli berupa roh-roh dan tenaga gaib 
yang masih kabur bentuk dan fungsinya, dalam kebudayaan India telah berupa dewa-dewa yang lebih nyata pribadinya dan sifat-sifatnya sebagai lambang tenaga-tenaga alam, yang mempunyai hierarki dan fungsi yang tentu dalam proses kosmos maupun dalam kehidupan manusia

Sekitar abad ke-14 beberapa kerajaan yang ada di Jawa dan belakangan di susul dengan Kerajaan Hindu Bali berusaha menganeksasi kerajaan-kerajaan di Lombok yang pada akhirnya membuahkan hasil dengan adanya akulturasi budaya spiritual dan material dengan budaya masyarakat asli. Karena itu akan jelas kelihatan mana budaya yang dapat terpengaruhi oleh kedatangan HinduBudha maupun yang masih asli.

Berdasarkan pemaparan itu untuk dapat menemukan beberapa ciri kebudayaan asli masyarakat primitif terutama dalam hal kepercayaan dan terjadinya adaptasi budaya antara kebudayaan Hindu-Budha dengan kebudayaan asli di Pulau Lombok-NTB, sesuai dengan anak judul di atas, maka paling tidak dengan mengkaji bagaimana kehidupan masyarakat pedesaan saat ini masih menyisakan kearifan kebudayaan masa lalu maupun yang sudah bersatu dengan budaya pendatang lainnya. Hal inilah yang di gunakan oleh antropolog untuk dapat mencari gambaran bagaimana budaya asli masyarakat sekitar. Dengan demikian ada dua hal yang kita akan cari yaitu, bagaimana kepercayaan primitif masyarakat (kepercayaan asli), dan akulturasi kebudayaan HinduBudha dengan kebudayaan asli di Pulau Lombok-NTB.

\section{B. METODE PENELITIAN}

Penelitian ini menggunakan metode historis dengan tujuan untuk mendeskripsikan dan menganalisis peristiwa-peristiwa dimasa lampau. Teknik pengumpulan data menggunakan teknik heuristik dan analisis data bersifat analisis data kualitatif. Selanjutnya data yang diperoleh dilakukan analisis dan sintesis untuk menyatukan fakta-fakta sejarah tentang kepercayaan animisme-dinamisme serta adaptasi kebudayaan hindubudha dengan kebudayaan asli di pulau Lombok-NTB.

\section{HASIL DAN PEMBAHASAN}

1. KePERCAyaAn ANimisme-Dinamisme di Pulau LomboKNTB

a. BEBERAPA ASPEK TEORITIS DAN GAMBARAN UMUM

Kepercayaan merupakan salah satu unsur budaya

yang sangat penting dalam kehidupan manusia, demikian pentingnya justru di belahan bumi mana pun kepercayaan merupakan bagian dari suprastruktur kehidupan masyarakat yang mempuni. Karena itu C. Kluckhohn (Soerjono Soekanto, 1982) seorang antropolog mengatakan bahwa agama (kepercayaan) merupakan salah satu unsur budaya yang sangat penting dan selalu ada dalah kehidupan masyarakat. Dan dari tujuh unsur kebudayaan sebagaimana di katakana Koentjaraningrat (Wiranata, 2002),

Berangkat dari sedikit penjelasan di atas maka untuk menemukan salah satu kunci untuk memahami kebudayaan awal di Indonesia secaya keseluruhan adalah memahami kepercayaan awal yang menjadi pedoman hidup anggota masyarakatnya, yang secara umum walaupun berbeda dalam konten bagaimana mengaplikasikan kepercayaan tersebut baik dalam cara ritual (penyembahan) maupun aplikasi sehari-hari pada masyarakat yang berbeda, namun menandaskan adanya suatu kepercayaan yang oleh ahli dinamakan kepercayaan animisme- dinamisme, bahkan juga totemisme dan fetishisme.

Kepercayaan animisme (dari bahasa latin anima atau "roh") adalah kepercayaan kepada mahluk halus dan roh merupakan asas kepercayaan agama yang mula-mula muncul di kalangan manusia primitif. Kepercayaan animism mempercayai bahwa setiap benda di bumi ini, (seperti kawasan tertentu, gua, pohon, atau batu besar) mempunyai jiwa yang mesti di hormati agar semangat tersebut tidak mengganggu manusia, malah membantu mereka dari semangat dan roh jahat dan juga dalam kehidupan seharian mereka.

Sedangkan dinamisme (dalam kaitan agama dan kepercayaan) adalah pemujaan terhadap roh nenek moyang yang telah meninggal menetap di tempat-tempat tertentu, seperti pohon-pohon besar. Arwah nenek moyang itu sering di mintai tolong untuk urusan mereka. Caranya adalah dengan memasukkan arwah-arwah mereka ke dalam benda-benda pusaka seperti batu hitam 
atau batu merah delima dan lain sebagainya. Serta ada juga yang menyebutkan bahwa dinamisme adalah kepercayaan yang mempercayai terhadap kekuatan yang abstrak yang berdiam pada suatu benda. Istilah tersebut disebut dengan mana'.

Adapun totemisme adalah faham yang meyakini bahwa manusia memiliki hubungan kekeluargaan dengan binatang. Kemudian keyakinan ini mengarahkan pengikutnya untuk meyakini bahwa ada beberapa binatang yang memiliki kekuatan gaib, lalu mereka mengkeramatkan binatang-binatang tersebut, bahkan sampai memujanya. Begitu juga dengan Fetish (diambil dari bahasa latin "facticius" yang berarti "artificial" and "facere", "to make") yang berarti sebuah benda yang di percayai memiliki sebuah kekuatan magis atau spiritual.

\section{b. Kepercayaan Awal Masyarakat Lombok}

Berdasarkan hasil penemuan arkeologis di Gunung Piring, Desa Teruwai Kecamatan Pujut, Lombok Selatan oleh proyek penggalian dan penelitian purbakala Jakarta tahun 1976 adalah periuk utuh, kerangka manusia, sisa kulit kerang, arang, pragmen logam dan binatang. Dari hasil tersebut, disimpulkan bahwa kira-kira pada akhir zaman perunggu, enam belas abad yang lalu pulau Lombok bagian selatan telah di huni oleh sekelompok manusia yang sama kebudayaannya dengan penduduk; (1) di Vietnam Selatan di Gua Tabon dan Gua Sasak, (2) penduduk di pulau Pallawan-Filipina, (3) penduduk di Gilimanuk Bali, (Penduduk di Malilelo-Sumba. Karena itu kenurut Drs. M.M. Sukarto dan Prof. Solhehim, guru besar Universitas Hawai, kebudayaan mereka di Gunung Piring itu termasuk ke dalam Shan Huyn Kalanny Tradition.

Pada zaman dahulu nenek moyang kita hidup berpindah-pindah dari satu tempat lainnya untuk mengumpulkan bahan makanan dari hewan dan tumbuhan. Masa seperti ini di sebut dengan masa meramu. Nenek moyang suku Sasak yang tinggal di daerah belangos, Sekaroh dan sekitarnya mulai bercocok tanam sehingga pada saat ini daerah tersebut kurang subur, itu sebabnya daerah Blangos, Sekaroh dan sekitarnya sekarang ini banyak di tumbuhi semak belukar.

Kehidupan nenek moyang kita pada saat itu sudah mulai menetap (bertempat tinggal) secara berkelompok. Dengan demikian, hidupnya sudah lebih teratur dan membentuk pemimpin-pemimpin di tempat tinggalnya. Keberadaan mereka yang sudah menetap, tidak hanya memikirkan bagaimana mereka akan menjalani hidup bersama sebagai bagian dari anggota masyarakat. Namun dengan keterbatasan manusia saja kita sudah di karuniai pemikiran bahwa ada sesuatu yang menguasai ala mini secara sempurna dan melebihi kekuatan manusia. Ini Pulalah yang menguasai pemikiran mereka setelah mereka hidup menetap berdasarkan pengalaman hidup yang mereka jalani sebelumnya.

Lalu Wacana (1977) menjelaskan kepercayaan masyarakat masa lampau tentang adanya mahluk-mahluk halus yang memiliki kekuatan (supranatural) dan sampai saat ini sebagian masih di percayai oleh masyarakat seperti:

1) Batara Guru. yaitu raja dewa-dewa yang menurunkan Raja Lombok

2) Bidedari, yaitu sebangsa dewi yang hidup di madya antara awing-awang

3) Babodo', yaitu sebangsa hantu yang berkeliaran bila waktu magrib tiba, terutama pada malam jum'at. Itulah sebabnya pada saat-saat itu, anak-anak di larang bermain-main di luar rumah. Karena di yakini bahwa Bebodo' suka menyembunyikan anak-anak kecil di bawah umur dan di beri makanan berupa ulat yang katanya kelihatanseperti nasi biasa. Bebodo dapat menyembunyikan anak-anak kecil dengan payudaranya yang sangat besar. Untuk menemukan anak yang hilang tersebut di pukulkan parang buntung dan di taburi garam besar. Karena masyarakat berkeyakinan bahwa bebodo' dan sejenisnya tidak suka dengan garam, karena itu jika di lempari dengan garam maka dia akan mengembalikan anak tersebut.

4) Bake', merupakan sebangsa hantu yang menurut nenek moyang suku Sasak sangat jahat dan bisa membuat manusia sakit. Tempat tinggalnya di hutan, batu-batu besar dan pohon kayu yang ridang.

5) Bebai, sejenis mahluk halus yang kecil, tidak semua orang dapat melihatnya. Bebai di pelihara oleh selak.

6) Sela', sebenarnya bukanlah mahluk halus melainkan manusia biasa. Seorang dapat menjadi sela' di sebabkan karena memiliki ilmu sejenis sihir. Oleh sebab itu ia dapat menjadi sesuatu sesuai kehendaknya. Ada juga orang menjadi selak karena 
keturunan, demikianlah juga orang yang beristrikan sela, maka dia cndrung untuk ikut menjadi sela'. Jenis sela' ini ada dua yaitu:

a) Selaq Beleq: kekuatannya lebih besar dan lebih hebat dalam menghancurkan kekuatan lawan. Umumnya sela' jenis ini memakan bangkai dan kotoran manusia. Mereka juga bisa berkumpul pada malam hari sesame sela'nya di tempat lapang untuk makan bangkai dan kotoran manusia bersama, dan inilah yang di sebut sangkep.

b) Selaq Bunge: Hidupnya di angkasa dan selalu mencari musuh di malam hari. Sela' bunge tidak memakan yang kotor seperti halnya sela' beleq.

Berdasarkan penjelasan di atas, di bawah ini saya akan mencoba mengidentifikasi beberapa kepercayaan tradisional masyarakat di Lombok yang saya kira jika kita bertolak pada cara yang di lakukan oleh antropolog untuk mendapatkan kepercayaan asli masyarakat awal dengan meneliti masyarakat pedesaan, maka kesimpulan yang dapat kita ambil tidak akan jauh berbeda dengan apa yang nenek moyang mereka percayai. Karena itu pada bagian ini saya akan menjelaskan dengan konteks saat ini untuk memunculkan kepercayaan masyarakat primitif yang terlebih dahulu menerapkan kepercayaan tersebut dalam kehidupannya sehari-hari.

\section{1) Dalam Bidang Pertanian}

Seperti sudah di jelaskan di atas bahwa pada umumnya pertanian merupakan pekerjaan yang mendominasi masyarakatnya, namun hal ini tidak sampai di situ saja, karena ada satu hal menarik yang perlu kita tahu pada kebudayaan masyarakat ini dalam hal pertanian ini. Mulai dari penentuan tanggal, dan hari yang bagus untuk menanam sampai pada kepercayaan dengan mantra-manta oleh orang yang ahli ketika hama menyerang tanaman sampai saat ini terus di percaya dan masih di lestarikan kepercayaan tersebut.

Langkah pertama yang biasanya diambil adalah menanyakan hari-hari yang bagus untuk penyemaian padi, hal ini bisa di tanyakan pada orang yang dianggap memiliki kekuatan spiritual yang bagus, dan di kecamatan Jerowaru kita tidak jarang akan bisa menemukan orang yang katanya mampu menunjukkan hari-hari yang bagus untu menanam padi.

\section{2) Benda-benda dan Binatang}

Beberapa binatang yang dapat merusak tanaman padi atau tanaman lainnya seperti ulat, tikus, dan babi di percayakan memiliki kekuatan, karena seperti yang di percayai masyarakat binatang tersebut di miliki oleh jin, karena itu mereka tidak berani menyumpahnya ketika merusak tanaman. hal ini bukan berarti mereka tidak berani membasminya melainkan mereka hanya takut untuk menyumpahnya, mereka meyakini kalau di sumpah maka yang empunya bakal marah. Kepercayaan seperti ini saat ini sudah mulai luntur namun masih ada sebagian masyarakat yang mempercayainya.

Kucing juga dianggap memiliki balak. Hal ini berlaku misalnya ketika di tabrak, dan yang menabrak tersebut tidak mengangkatnya dan serta menguburkannya maka oleh masyarakat di percayai suatu saat dalam perjalanan sang pengendara tersebut akan mendapatkan bahaya. Penguburannnya juga tidak sembarangan, melainkan harus di bungkus menggunakan pakaian yang digunakan oleh orang yang menabrak tadi, bahkan lebih bagus lagi jika di bungkus dengan kain putih sebelum di masukkan dalam tanah.

\section{3) Pembuatan Bangunan}

Salah satu kepercayaan masyarakat sampai saat ini yang bertendensi kearah religius-magis dalam hal ini adalah saat pembangunan rumah misalnya. Masyarakat percaya bahwa harus di yakinkan bahwa di bawah pondasi tempat pembuatan rumah tersebut tidak ada batu besar. Karena batu besar dianggap sebagai tempat jin, dan jika mereka membuat rumah di atasnya maka di hawatirkan suatu saat mahluk gaib yang menghuni batu besar tersebut akan mengganggu pemilik rumah. Bukan hanya itu jika secara kasat mata batu besar tersebut tidak dapat di lihat maka mereka menggunakan tenaga ahli paranormal untuk memastikan bahwa tempat di mana akan di bangun rumah tersebut steril dari pengaruh jin dan mahluk gaib lainnya.

\section{4) Kemalik dan Ketobok}

Kemalik dan ketobok memiliki objek yang dapat di lihat, baik berupa bangunan maupun hanya berupa benda. Antara kemalik dan ketobok ini memiliki perbedaan yang dapat kita pisahkan. Kemalik sering berupa batu besar, pohon besar dan kadang-kadang sebuah tempat yang kelihatan biasa-biasa namun di yakini oleh masyarakat di 
huni oleh banyak mahluk halus. Mahluk halusnya di yakini bisa berupa jin ular, jin kera, jin yang tua, dan lain sebagainya yang menguasai tempat tersebut. Anak-anak ataupun orang dewasa dilarang untuk bermain di tempat tersebut kalau tidak memiliki mantra yang bisa mengalahkan jin tersebut. Karena itu biasanya di ajarkan pada anak-nak mereka mantra supaya mereka tidak terkena pengaruh jin yang ada di tempat tersebut. Yang nyata dapat kita lihat mengenai kemalik ini misalnya di Kadus Batu Tambun Desa Wakan. Kemalik ini berupa pohon besar yang di yakini oleh masyarakat sekitar di huni oleh banyak jin, bahkan oleh masyarakat sana di yakini sebagai tempat tinggalnya banyak jin, kemalik ini memiliki seorang pemangku yang menjaga tempat tersebut. Bukan hanya itu di bawah pohon besar tersebut di buatin semacam gubuk yang di yakini sebagai tempat istirahatnya mahluk gaib yang menghuni sekitar pohon tersebut. Sedangkan orang yang berani masuk dan membersihkan apa lagi memotong-motong ranting tersebut hanyalah pemangku kemalik tersebut. Kemalik ini juga bukan hanya berupa pohon, dan batu besar saja namun juga dapat berupa bangunan-bangunan tua, seperti sumur tua, pondasi masjid dan bangunan-bangunan lainnya.

Sedangkan ketobok berupa bangunan yang di buat masyarakat tidak berselang terlalu lama dan bangunannya dapat di perbaharui, baik di buat dengan beratapkan ilalang dan bertembokkan pager (bedek), serta ada juga yang temboknya terbuat dari batu bata dan di bangun seperti rumah kecil modern. Ketobok di buat karena di yakini oleh masyarakat sekitar bahwa di tempat tersebut pernah di tinggali oleh orang suci atau orang alim, atau katakanlah wali. Tokoh tersebut bisa saja di percayai pernah tinggal lama atau hanya sekedar tempat singgah, atau pun juga di yakini sebagai tempat menghilangnya orang suci tersebut. Misalnya ketobok yang ada di desa Wakan di perkirakan pernah di tempati oleh salah seorang tokoh yang bernama Mercesari. Tokoh ini di yakini oleh masyarakat sekitar sebagai orang alim dan sekaligus jelmaan dari wali yang membangun masjit Rambitan di kecamatan Pujut Lombok Tengah. Lain halnya dengan ketobok yang ada di desa ganti, menurut keyakinan masyarakat bahwa di tempat inilah sunan gunung jati menghilang pada saat menyiarkan agama Islam ke pulau Lombok.

Sama halnya dengan kemalik, ketobok juga memiliki seorang pemangku yang kiranya dapat mengajarkan tata cara untuk berdoa dan melakukan ritual, ataupun sesajian setiap tahun yang di lakukan oleh masyarakat. Ketobok ini oleh masyarakat sekitar di yakini dapat memberikan banyak berkah, misalnya sebagai tempat untuk meminta supaya rizkinya banyak, sembuh dari penyakit, sampai pada tempat untuk meminta hujan. Demikianlah yang di lakukan oleh masyarakat di sekitar ketobok yang ada di Rempung Puntik Kecamatan Ganti. Mereka membawa sesaji, mereka makan bersama di tempat tersebut, dengan membawa kesenian seperti gamelan dan lain sebagainya, sekaligus berdoa meminta berkah serta di turnkan hujan. Inilah sedikit dari kepercayaan masyarakat tentang ketobok yang sebenarnya masih banyak segi-segi lain yang perlu di ulas namun membutuhkan tempat yang lebih banyak.

\section{5) Bebubus}

Bebubus merupakan salah satu kepercayaan masyarakat bahwa dengan cara tersebut mereka bisa sembuh dari penyakit yang di deritanya, di saat bebubus bisa meminta rizki yang banyak, di panjangkan umurnya dan lain sebagainya. Pada umumnya bebubus ini di lakukan pada hari senin yang di kenal dengan nama bubus senin, dan hari jum'at. Selain bubus yang di buat supaya yang memakainya bisa mendapatkan kebaikan, kesehatan, terhindar dari pengaruh gaib yang jahat sekaligus ada juga bubus yang di yakini dapat menarik hati peria atau wanita ketika di gunakan, namun pembuatan bubus semacam ini di lakukan secara sembunyi dan di rahasiakan. Adapun macam acara bebubus yang pertama terbuka dan di ketahui oleh umum, karena yang menggunakannya juga adalah masyarakat pada umumnya.

Bubus pada umumnya terbuat dari beras yang di tumbuk, dan di campur dengan bahan-bahan yang lainnya, pada saat pembuatannya juga tidak luput dari mantramantra, karena di sanalah inti dari pembuatannya. Karena itu bubus ini memiliki seorang pemangku, dan di warisi secara turun-temurun oleh keluarga pemangku tersebut. Bebubus ini sekaligus juga memiliki ikatan bubus, baik berupa kekerabatan maupun tempat tinggal. Dengan 
demikian walaupun berasal dari desa yang berbeda namun kadang-kadang pergi bebubus ke desa yang lain karena ikatan kekerabatan dengan pemangku bubus tersebut.

Masyarakat juga percaya bahwa pemangku bubus tersebut di kelilingi banyak mahluk halus, dan banyak juga orang yang bisa kena kejahatan mahluk halus yang di percayai sebagai penunggu bubus tersebut, misalnya mereka akan hilang kesadaran dan mengamuk, gejala pingsan atau bahkan sakit. Semuanya itu jika yang menyebabkan semuanya adalah mahluk halus yang ada pada bubus tersebut maka yang akan mengobatinya juga adalah pemilik bubus, atau paling tidak akan bisa sembuh setelah minum air bubus yang remas dan di usap-usap ke mukanya.

\section{6) Dukun/tabib}

Fungsi tabib sampai saat ini pada masyarakat pedesaan di kecamatan Jerowaru sama dengan fungsi seorang dokter, bahkan mereka lebih dahulu di tuju sebelum orang yang sakit tersebut di bawa ke dokter atau rumah sakit. Mereka bukan hanya bisa menyembuhkan satu penyakit, namun kadang-kadang menurut keyakinan masyarakat terdapat dukun yang memiliki kemampuan mantra pada penyakit yang berbeda. Cukup dengan komat kamit dan di sediakan mangkok berisi beras, lingkaran benang, cabe tandan, segelas air serta uang seadanya bisa satu atau dua ribu, setelah itu yang sakit tersebut akan di kasi minum air yang pernah di kasi mantera tadi, dan si dukun akan bilang penyakitnya sebentar lagi akan sembuh. Setelah tidak ada perubahan sama sekali atau bahkan semakin bertambah sakit baru langsung pergi ke rumah sakit. Bahkan di rumah sakit pun ada saja warga yang dengan kepercayaan dirinya memiliki mantra untuk menyembuhkan penyakit seperti itu dan mencoba untuk membantunya dengan mantra di ruangan rumah sakit.

\section{7) Benda Pusaka dan Azimat}

Terkait dengan benda pusaka seperti keris, tumbak dan senjata lainnya yang dianggap memiliki kekuatan lain, akan banyak kita temukan di tempat lain. Karena itu dalam hal ini kami akan membataskan diri pada azimat. Azimat oelh masyarakat di percaya memiliki kekuatan untuk untuk menagkal tindakan-tindakan yang jelek dari orang lain baik secara pisik maupun psikis.
Azimat/bebadong ini bisa berupa kain, beberapa tulisan kertas maupun semacam minyak. Azimat atau bebadong yang terbuat dari kain biasanya berbentuk sabuk, hingga dalam keadaan yang berbahaya azimat tersebut dapat di gunakan sebagai sabuk. Begitu juga hanya dengan azimat berupa tulisan atau gambar alqur'an atau tulisan jawi, biasanya berukuran kecil dan dapat di masukkan dalam katong, sehingga oleh pemiliknya dapat di bawa kemanapun kecuali saat kencing dan membuang air besar, karena jika di bawa pada dua kegiatan tersebut di pecaya kekuatannya akan berkurang.

Bebading atau azimat yang berupa minyak oleh masyarakat di yakini dapat menyebabkan tubuh si pemilik menjadi kebal dari pengaruh besi ataupun benda-benda tajam lainnya setelah di minum atau sekedar di oleh di sebagian tubuhnya. Pembuatan minyak azimat ini tidak sembarangan, karena dalam pembuatannya di perlukan orang yang memiliki keahlian dalam hal itu untuk melakukan mantra untuk memberikan kekuatan spiritual pada minyak yang di buat sebagai azimat tersebut. Sama seperti pembuatan minyak kelapa yang lainnya, membuat minyak azimat ini juga seperti itu, namun perbedaannya ketika tempurung kelapanya di pisahkan dari isinya, maka isinya tidak boleh cacat oleh parang yang di gunakan. Karena di yakini dengan tidak cacatnya isi kelapa tersebut akan berpengaruh pada kekebalan tubuh yang tidak akan cacat juga jika terkena benda tajam ketika ada musuh.

\section{8) Mantra-mantra Kekebalan Tubuh}

Seperti di jelaskan di atas bahwa bebadon atau azimat juga bertujuan untuk membuat tubuh si pemiliknya menjadi kebal dari pengaruh benda-benda tajam seperti keris, maupun tumbak jika di gunakan untuk membela diri di saat kepepet maupun ketika berhadapan dengan musuh. Selain itu kekebalan tubuh ini juga berupa mantra-mantra yang harus di kuasai oleh seseorang supaya tidak perlu lagi membawa bebadong atau azimat yang kadang-kadang lupa di bawa. Sedangkan mantra ini akan melekat pada individunya sebagai pelindung.

Mantra-mantra untuk dapat membuat tubuh menjadi kebal ini terdapat dua bentuk yaitu ada yang di namakan ilmu masak dan ilmu katak. Ilmu masak adalah ilmu kekebalan tubuh yang di ajarka oleh seseorang dengan cara biasa-biasa tanpa harus dengan persyaratan, 
bisa di ajarkan saat duduk nyantai dan sebagainya. Sedangkan ilmu masak di ajarkan oleh sang guru di tempat-tempat tertentu yang tersembunyi, serta pada bulan tertentu. Biasanya ilmu katak (belum masak) ini diajarkan pada bulan maulid, dengan persyaratan yang diajarkan bisa berjumlah lebih dari satu orang, mengasingkan diri di tempat yang sunyi selama satu minggu, yang di mulai hari jum'at dan di akhiri hari jum'at juga. Ilmu kekebalan tubuh ini dianggap sudah masuk jika saat tidurnya di tempat persembunyiannya bermimpi naik ke tempat yang tinggi, masuk dalam masjid atau menunggang sesuatu, dan hal ini biasanya akan di tanyakan oleh sang guru mimpi muridnya pada malam hari, dan jika sang murid menceritakan seperti demikian maka dianggap ilmunya sudah akan mencapai ke sempurnaan untuk menguasai ilmu kekebalan tersebut.

\section{9) Kemenyan}

Tujuan dari diadakannya kemenyan ini oleh masyarakat di yakini akan dapat menerangkan arwah nenek moyang yang telah meninggal du nia di alam sana, begitu juga nanti setelah orang yang menyalakan kemenyan itu meninggal dunia, mereka memiliki keyakinan bahwa akan mendapatkan ketenangan di alam ahirat nanti dengan melakukan kemenyan tersebut.

Kemenyan ini di lakukan pada tanggal 15 bulan ramadhan, karena masyarakat menganggap bahwa pada pertengahan bulan tersebut yang pada awal ramadhan arwah keluarganya yang telah meninggal dunia pulang ke rumahnya, namun pada pertengahan bulan tersebut di yakini bahwa arwah mereka akan kembali ke tempat asalnya, jadi dengan adanya kemenyan yang di nyalakan pada pada malam hari tersebut tidak lain adalah untuk menerangi perjalanan pulang arwah nenek moyangnya kea lam kubur.

Adapun pembuatan dari kemenyan ini, yaitu buah jarak yang di masukkan pada penusuk lidi yang jumlahnya tidak terbatas. Kemenyan ini lalu di nyalakan di sekeliling rumah dan di tempat-tempat yang dianggap penting. Pada intinya penempatan kemenyan ini sesuai dengan di mana seharusnya lampu ada, baik di dapur, ruang makan, depan teras, kamar mandi dan bahkan di jalan-jalan yang di lewati orang.

10) Pelet, Senggeger, dan Sengasih-asih
Pelet adalah mantra yang di gunakan seorang lakilaki atau perempuan untuk membuat pacarnya jatuh cinta sama penggunanya, biasanya pelet ini terkesan sebagai mantra yang kurang bagus di mata orang banyak karena di yakini dapat memaksakan cinta pada orang yang sebenarnya tidak mencintainya, dan yang paling parah lagi jika mereka dapat menikah, maka masyarakat yakin kalau dia dapat pasangannya tersebut dengan menggunakan pellet maka tidak akan berjalan lama, karena pada saat tertentu ketika pengaruh pellet tersebut tidak berpengaruh lagi maka perempuan atau laki-laki yang terkena pellet tersebut akan membenci suami atau istrinya, karena pada awalnya tidak di dasari rasa cinta yang murni. Karena itu penggunaan pelet bagi masyarakat adalah sesuatu yang kurang bagus.

Adapun cara penggunaan pellet ini bisa lewat rokok, uang, mata, sabut, atau makanan yang di berikan pada seorang gadis, dan disanalah di lakukan mantramantra. Sedangkan senggeger dan sengsih-asih hempir merupakan sesuatu yang sama dan dianggap bagus olah masyarakat, karena hanya akan menimbulkan kesenangan bagi orang lain melihat kita. Jika senggeger di gunakan untuk dapat di lihat menarik oleh pasangan kita, maka sengasih-asih di percaya dapat mempengaruhi orang banyak pada umumnya.

\section{Adaptasi Budaya Hindu-Budha Terhadap Budaya Lokal dan Sebaliknya di Pulau Lombok-NTB. \\ a. Gambaran Umum}

Sasak traditional merupakan etnis mayoritas penghuni pulau Lombok, suku Sasak merupakan etnis utama meliputi hampir 95\% penduduk seluruhnya. Bukti lain juga menyatakan bahwa berdasarkan prasasti tong tong yang ditemukan di Pujungan, Bali, Suku Sasak sudah menghuni pulau Lombok sejak abad IX sampai XI Masehi, Kata Sasak pada prasasti tersebut mengacu pada tempat suku bangsa atau penduduk seperti kebiasaan orang Bali sampai saat ini sering menyebut pulau Lombok dengan gumi sasak yang berarti tanah, bumi atau pulau tempat bersembunyinya orang sasak.

\section{b. Beberapa Adaptasi Budaya Hindu-Budha dan Kebudayaan Asli di Pulau Lombok. \\ Perkembangan agama dan kebudayaan Hindu-}

Budha di Indonesia sangat bisa menyesuaikan diri dengan budaya lokal yang pernah ada. Bahkan untuk membedakan 
kebudayaan hindu asli (India), salah satu tempat di mana agama dan kebudayaan ini berkembang pesat yaitu di Bali, di namakan Hindu Bali. Karena memiliki karakteristik tersendiri yang membedakannya dengan kepercayaan dan kebudayaan Hindu-Budha di daerah asalnya.

\section{1) Kasta Sosial}

Dalam kebudayaan India kita mengenal adanya kasta sosial seperti Brahmana, Ksatria, Waisya dan sudra. Keempat strata sosial ini sifatnya tertutup (closed status). Dalam perkembangannya ke kawasan lain seperti di nusantara, terlebih lagi setelah kerajaan-kerajaan besar secara tidak langsung sebagai kerajaan Hindu-Budha di kawasan ini mengadopsi juga adanya kasta sosial dalam lingkup kerajaan.

\section{2) Adat-Istiadat Dalam Sistem Perkawinan}

Adat kawin lari (melaian), acara ngiring dan beberpa prosesi dalam sistem perkawinan lainnya tidak terlalu jauh berbeda dengan sistem perkawinan yang ada di Bali. Sampai saat ini adaptasi budaya perkawinan ini masih merupakan salah satu ciri dari masyarakat sasak. Selain itu setelah prosesi selamatan kemudian di adakan prosesi selanjutnya yaitu mengikuti (ngiring) penganten ke rumah orang tuanya dengan menggunakan gendang belek atau kecimol (semacam kesenian rakyat yang diadaptasi dari kebudayaan Hindu Bli juga)

\section{3) Sapuk}

Sapuk merupakan ikat kepala yang di gunakan oleh tokoh adat ketika acara bait wali untuk menentukan kapan anaknya yang di larikan itu akan di nikahkan, dalam hal ini juga di bicarakan berapa harga yang harus di bayar oleh pengantin laki-laki. Sapuk juga digunakan untuk acara ngiring (mengantar mempelai ke rumah orang tua perempuan dengan cara ramai-ramai dan di ikuti beberapa kesenian sasak seperti gendang belek dan lain-lain). Selain di gunakan sebagai pelambang dalam beberapa hal seperti yang di sebutkan di atas bagi orang tua juga biasa menggunakan sapuk dalam kehidupannya sehari-hari.

Sapuk yang digunakan sebagai perlengkapan dalam bebecara prosesi perkawinan di atas ternyata merupakan pakaian yang digunakan masyarakat bali ketika acara nyongkolan seperti yang di lakukan di Lombok sekaligus digunakan ketika upacara keagamaan.
Inilah yang di adaptasi oleh masyarakat Sasak sebagai bagian dari pakaian dalam beberapa prosesi perkawinan.

\section{4) Aksara}

Aksara jejawan di Lombok sama dengan aksara yang ada di Bali. Dengan begitu jelas dalam beberapa hal masyarakat sasak lebih banyak mengadaptasi beberapa hal penting untuk kehidupan masyarakatnya dari kebudayaan Hindu Bali. Hal ini memang karena letaknya yang strategis dan berdekatan untuk secara cepat beberapa kebudayaan yang ada di masing-masing pulau untuk cepat beradaptasi. Sedangkat huruf jejawan yang berkembang di Jawa lebih banyak dua huruf, sedangkan aksara jejawan yang ada di Bali dan Lombok kurang dua huruf.

\section{5) Kesenian}

Beberapa kesenian masyarakat yang sampai saat ini masih terus di lestarikan seperti wayang, gamelan, gendang belek, dan lain sebagainya merupakan kesenian yang di adaptasi dari kebudayaan Hindu Bali, dan sedikit dari kebudayaan Hindu Jawa. Gamelan misalnya, sebagaimana halnya di bali, begitu juga halnya di pulai Lombok, meskipun pada akhirnya akan di sesuaikan dengan budaya lokal. Begitu juga dengan pewayangan, dimana kebanyakan ceritanya mengikuti alur cerita dan nama dari tokoh Hindu, dan sebagian di modifikasi dengan nama lokal.

\section{SIMPULAN DAN SARAN}

Kepercayaan awal masyarakat Sasak di Pulau Lombok tidak berbeda dengan perkembangan awal masyarakat pada umumnya yang di pengaruhi oleh kepercayaan religius magis. Pada saat itu kepercayaan masyarakat akan kekuatan dari kosmologi sangat kuat sehingga secara tidak langsung sosio-kultural yang di bangunnya dalam kehidupannya sehari-hari berdasarkan kepercayaannya pada kekuatan gaib tersebut. Pada masyarakat Sasak di Lombok-NTB pada saat itu di kenal juga kepercayaan animism, dinamisme dan totemisme.

Kepercayaan masyarakat tersebut dapat berupa kepercayaan terhadap benda-benda yang memiliki kekuatan gaib (dinamisme), seperti, ketobok, makam, kemalik, keris, tombak dan lain sebagainya. Ada juga kepercayaan masyarakat pada mahluk-mahluk halus yang menguasai suatu tempat atau benda (animism), seprti 
dalam hal pembangunan, pohon besar dan lain sebagainya.

Masyarakat juga percaya bahwa beberapa binatang memiliki kekuatan gaib (totemisme) seperti tikus, babi, kucing dan ular.

Kebudayaan masyarakat sebelumnya, setelah kedatangan pengaruh Hindu-Budha terutama setelah pengaruh kerajaan Hindu Bali menganeksasi secara defakto kerajaan Lombok di Mataram Cakra Negara, beberapa kebudayaan yang di bawa oleh orang-orang Bali mampu beradaptasi dengan budaya local, bahkan sampai saat ini budaya yang dikembangkannya tersebut menjadi salah satu budaya dari masyarakat Sasak, seperti dalam hal kesenian, bangunan, aksara dan lain sebagainya.

\section{DAFTAR RUJUKAN}

Alisyahbana S. Takdir. 1988. Revolusi Masyarakat dan Kebudayaan di Indonesia. Dian Rakyat: Jakarta.

Budiwanti, Erni. 2002. Islam Sasak. LKIS, Yogyakarta.

Mulyana, Agus \& Darmiasti. 2009. Historiografi di Indonesia:dari magis-religius hingga strukturis. Reflika Aditama: Bandung.

Muhsipuddin. 2004. Kilas Balik 100 Tahun Pendidikan di Lombok Timur.

Salam, Solechin. 1992. Lombok Pulau Perawan. Kuning Mas, Jakarta.

Soedjatmoko, Ali Muhammad, dkk (ed). 1995. Historiografilndonesia: sebuah pengantar. Gramedia Pustaka Utama: Jakarta.

Soekanto Soerjono. 1999. Sosiologi Suatu Pengantar. Rajagrafindo Persada: Jakarta.

Supardan, Dadang. 2011. Pengantar Ilmu Sosial. Bumi Aksara: Jakarta.

Wiranata I Gede. 2002. Antropologi Budaya. Citra Aditya Bakti: Bandung 